DOI: $10.12731 / 2070-7568-2020-2-255-276$

УДК 331.108

\title{
КАДРОВЫЙ РЕЗЕРВ \\ КАК НАПРАВЛЕНИЕ РАЗВИТИЯ ПЕРСОНАЛА: \\ ПРАКТИКА ИССЛЕДОВАНИЯ И СОВЕРШЕНСТВОВАНИЯ НА ПРОМЫШЛЕННОМ ПРЕДПРИЯТИИ
}

\section{Шендель Т.В.}

В статье проведено исследование понятия "развитие персонала», определена его роль для предприятия в современных условиях функиионирования. Выявлено сущностное содержание кадрового резерва как организационно-экономического мероприятия в развитии персонала предприятия. Предметной областью исследования 6 данной статье явилось промьиленное предприятие Красноярского края и его особенности работы с кадровым резервом. В результате исследования выявлены высокий коэффициент текучести среди резервистов, отсутствие их практической подготовки, несовершенство прочедуры выдвижения кандидатов на ключевую должность. Это определило объективную потребность в разработке рекомендаций по совершенствованию кадрового резерва как направления развития персонала на промышленном предприятии Красноярского края. Устранение данных недостатков позволит развивать SoftSkills \& HardSkills у резервистов, сформировать у них чувства причастности и вовлеченности в деятельность предприятия, обеспечить реализацию условий управления карьерой персонала и, следовательно, сделает резервистов конкурентоспособными.

Цель-исследование и совершенствование кадрового резерва как направления развития персонала на промышленном предприятии Красноярского края.

Метод или методология проведения работы: методы теоретического исследования (анализ и синтез информации), контент анализ, аналитические и статистические методы, сочиологические исследования (анкетирование). 
Результаты: предложены рекомендации по совершенствованию работы с кадровым резервом как направления развития персонала на промышленном предприятии Красноярского края - управление процессом текучести среди резервистов, совершенствование плана индивидуального развития резервистов, регламентация проиедуры выдвижения кандидатов на ключевую должность.

Область применения результатов: предложенные рекомендации по работе с кадровым резервом могут быть использованы на крупных предприятиях различных отраслей народного хозяйства.

Ключевые слова: персонал; развитие персонала; кадровый резерв; исследование кадрового резерва; совершенствование работы с кадровым резервом.

\section{PERSONNEL RESERVE AS A DIRECTION OF PERSONNEL DEVELOPMENT: PRACTICE OF RESEARCH AND IMPROVEMENT IN AN INDUSTRIAL ENTERPRISE}

\section{Shendel T.V.}

The article studies the concept of "personnel development", defines its role for the enterprise in modern operating conditions. The essential content of the personnel reserve as an organizational and economic event in the development of the enterprise's personnel is revealed. The subject area of research in this article is the industrial enterprise of the Krasnoyarsk territory and its features of working with the personnel reserve. The study revealed a high turnover rate among reservists, their lack of practical training, and imperfect procedures for nominating candidates for a key position. This determined the objective need to develop recommendations for improving the personnel reserve as a direction of personnel development at an industrial enterprise in the Krasnoyarsk territory. Eliminating these shortcomings will allow reservists to develop SoftSkills \& HardSkills, create a sense of ownership and involvement in the compa$n y$ 's activities, ensure the implementation of the conditions for managing the career of personnel and, consequently, make reservists competitive. 
Purpose - research and improvement of the personnel reserve as a direction of personnel development at an industrial enterprise of the Krasnoyarsk territory.

Methodology: methods of theoretical research (analysis and synthesis of information), content analysis, analytical and statistical methods, sociological research (questionnaires).

Results: recommendations for improving the work with the personnel reserve as a direction of personnel development at an industrial enterprise in the Krasnoyarsk territory are proposed: managing the turnover process among reservists, improving the plan for individual development of reservists, regulating the procedure for nominating candidates for a key position.

Practical implications: the proposed recommendations on working with the personnel reserve can be used at large enterprises in various sectors of the national economy.

Keywords: personnel; personnel development; personnel reserve; research of the personnel reserve; improvement of work with the personnel reserve.

\section{Введение}

В современных условиях SoftSkills \& HardSkills, сформированные у персонала, становятся важным стратегическим ресурсом предприятия, поскольку способствуют повышению заинтересованности персонала в эффективной реализации своих трудовых функций и, как следствие, достижению высоких экономических результатов в его деятельности, созданию благоприятного социально-психологического климата в коллективе.

Интересной является точка зрения Е.В. Демидовой, в соответствии с которой SoftSkills позволяют быть успешным независимо от специфики деятельности и направления, в котором работает человек. За это отвечают личностные качества и способности такие, как умение убеждать, находить подход к людям, лидировать, межличностное общение, работа в команде, личностное развитие, управление временем, эрудированность, креативность и т. д. SoftSkills важны как в работе, так и в жизни [4, с. 105]. 
В этой связи развитие персонала предприятия является одной из основных функций системы управления персоналом, поскольку современные условия функционирования характеризуются высоким темпом научно-технического развития, постоянными изменениями в законодательной базе и т. д. При этом не исключен процесс «устаревания» знаний, умений и навыков персонала, что требует их постоянного обновления.

Целью данной научной работы является исследование и совершенствование кадрового резерва как направления развития персонала на промышленном предприятии Красноярского края.

Руководствуясь поставленной целью, в качестве основных задач определены:

- рассмотреть теоретические основы работы с кадровым резервом как направления развития персонала;

- исследовать работу с кадровым резервом на промышленном предприятии Красноярского края;

- разработать рекомендации по совершенствованию работы с кадровым резервом как направления развития персонала на промышленном предприятии Красноярского края.

Само по себе понятие «развитие персонала» в научной литературе характеризуется гетерогенностью и неопределенностью. В этой связи представим в таблице 1 выдержки из научных трудов некоторых учёных.

Таблиияа 1.

Трактовки понятия «развитие персонала»

\begin{tabular}{|l|l|}
\hline $\begin{array}{c}\text { Автор } \\
\text { определения }\end{array}$ & \multicolumn{1}{|c|}{ Определение понятия } \\
\hline А.П. Егоршин & $\begin{array}{l}\text { Комплексный и непрерывный процесс всестороннего развития } \\
\text { личности работников предприятия с целью повышения эффек- } \\
\text { тивности их деятельности. }\end{array}$ \\
\hline В.М. Маслова & $\begin{array}{l}\text { Совокупность мероприятий, направленных на развитие чело- } \\
\text { веческого потенциала предприятия. }\end{array}$ \\
\hline Р. Харрисон & $\begin{array}{l}\text { Представления о способностях и потенциале персонала, заня- } \\
\text { тых в стратегической структуре бизнеса в целом. }\end{array}$ \\
\hline П.Э. Шлендер & $\begin{array}{l}\text { Система мероприятий, направленных на поддержку способных } \\
\text { кобучению работников, распространение знаний и передового } \\
\text { опыта, обучение молодых квалифицированных сотрудников. }\end{array}$ \\
\hline
\end{tabular}


Рассмотрев трактовки понятия «развитие персонала» ученыхисследователей, отметим, что это процесс его подготовки к выполнению новых производственных функций, замещению новых должностей, решению качественно новых задач.

Продолжая рассуждать о развитии персонала, стоит отметить его основные организационно-экономические мероприятия, реализуемые службой управления персоналом. Это переподготовка, повышение квалификации персонала; деловая оценка кандидатов на вакантную должность; адаптация персонала; текущая периодическая оценка кадров; работа с кадровым резервом. В контексте данного исследования наибольший интерес представляет кадровый резерв и особенности работы с ним. В этой связи считаем необходимым остановиться на данном организационно-экономическом мероприятии подробнее.

Современные условия подчеркивают острую потребность в управленцах нового поколения - творческих, активных, предприимчивых специалистах, способных самостоятельно решать разнообразные задачи в нестандартных меняющихся условиях, выполнять новые функции, занимать ключевые должности на предприятии. В связи с этим перспективным и актуальным направлением в развитии персонала является работа с кадровым резервом [1, с. 340]. Продолжая логику изложения материала, рассмотрим определения кадрового резерва, представленные в таблице 2 .

Анализ содержания кадрового резерва позволяет отметить в представленных понятиях единую теоретическую основу, заключающуюся в том, что кадровый резерв - это специальным образом отобранная группа специалистов и руководителей, характеризующихся высокими профессиональными результатами, обладающих лидерскими качествами, соответствующих определённым требованиям, ориентированных на карьерный рост посредством служебнопрофессионального продвижения на предприятии. Особо отметим значимость служебно-профессионального продвижения на предприятии в современных условиях, характеризующихся недостаточно сбалансированным российским рынком труда в профессиональном и квалификационном аспектах и, как следствие, наличием проблемы нехватки высококвалифицированного персонала [10, с. 209]. 
Таблицุа 2.

Трактовки понятия «кадровый резерв»

\begin{tabular}{|l|l|}
\hline \multicolumn{1}{|c|}{$\begin{array}{c}\text { Автор } \\
\text { определения }\end{array}$} & \multicolumn{1}{c|}{ Определение понятия } \\
\hline $\begin{array}{l}\text { Т.Ю. Базаров } \\
\text { Б.Л. Еремин }\end{array}$ & $\begin{array}{l}\text { Работники предприятия, способные в нужный момент выполнять } \\
\text { обязанности на новом участке работы. }\end{array}$ \\
\hline А.П. Егоршин & Один из методов подбора персонала. \\
\hline Л.И. Иванкина & $\begin{array}{l}\text { Специально сформированная на основе установленных критериев } \\
\text { группа перспективных работников, обладающих необходимыми } \\
\text { для выдвижения профессионально-деловыми, личностными и мо- } \\
\text { рально-этическими качествами, положительно проявивших себя } \\
\text { на занимаемых должностях, прошедших необходимую подготовку } \\
\text { и предназначенных для замещения определенных должностей. }\end{array}$ \\
\hline А.Я. Кибанов & $\begin{array}{l}\text { Потенциально активная и подготовленная часть персонала пред- } \\
\text { приятия, способная замещать вышестоящие должности, а также } \\
\text { часть персонала, проходящая планомерную подготовку для за- } \\
\text { нятия рабочих мест более высокой квалификации. }\end{array}$ \\
\hline Ю.Г. Одегов & $\begin{array}{l}\text { Специально сформированная группа работников, соответствую- } \\
\text { щая по своим качествам требованиям, предъявлемым к руково- } \\
\text { дителям определённого уровня, прошедшая процедуру отбора, } \\
\text { специальную управленческую и профессиональную подготов- } \\
\text { ку и потенцильно способная к управленческой деятельности. }\end{array}$ \\
\hline
\end{tabular}

\section{Материалы и методы}

Исследование работы с кадровым резервом является важным механизмом регулирования деятельности предприятия по обеспечению руководящими кадрами. По нашему мнению, целесообразно использовать организационно-аналитический, экономический и социально-психологический методы.

Организационно-аналитический метод рекомендуем использовать первоначально при организации исследовательской деятельности. В частности, этот метод предполагает применение контентанализа как формализованного (количественного) метода изучения документов, предполагающего оценку их содержания путём подсчёта признаков, существенных для исследования и удобных для последующего обобщения. Особенность контент-анализа состоит в том, что изучаются документы в их социальном контексте [9].

Практическое применение экономического метода - это второй этап в исследовательской деятельности. Оценка и текущий контроль 
деятельности по управлению кадровым резервом проводится по пяти основным направлениям, представленным на рисунке 1. Это предполагает определение количественных показателей, описывающих состояние кадрового резерва предприятия.

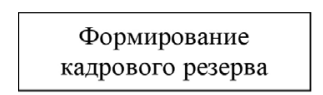

1. Движение кадрового резерва

2. Подготовка кадрового резерва

Обратная связь при подготовке кадрового резерва

Рис. 1. Основные направления работы кадрового резерва

Одним из инструментов социально-психологической группы методов является анкетирование, позволяющее на основе письменных ответов на предложенные вопросы выявить точки зрения и тенденции, имеющие место в группе респондентов [7].

Итак, исследование работы с кадром резервом проводилось на промышленном предприятии Красноярского края, основной вид деятельности которого - производство электрической энергии (мощности). Продолжая логику изложения материала, представим результаты исследования.

Анализ Положения о работе с кадровым резервом промышленного предприятия с использованием контент - анализа позволяет сделать следующие заключения. Положение утверждено генеральным директором предприятия в 2017 г. В документе определены цели, задачи, принципы, порядок формирования, развития и перемещения кадрового резерва предприятия. Структура Положения - 7 разделов, включающих 10 подразделов и 6 приложений. Акцентируем внимание, что в подпункте об обучающих и развивающих мероприятиях индивидуального плана развития не описана практическая подготовка резервистов.

Изучив Положение о подборе кадров, отметим, что поиск кандидатов осуществляется за счет внутренних и внешних ресурсов предприятия. Особо отметим, что в данном документе не прописано, каким образом осуществляется подбор персонала на руководящие должности предприятия. 
Далее представим результаты расчета количественных показателей, описывающих состояние кадрового резерва на промышленном предприятии Красноярского края, которые отражены в таблице 3.

Таблиияа 3.

Показатели, характеризующие кадровый резерв промышленного предприятия Красноярского края, 2019 г.

\begin{tabular}{|c|c|c|}
\hline $\begin{array}{l}\text { № } \\
\text { п/ா }\end{array}$ & Показатель & Определение показателя \\
\hline \multicolumn{3}{|c|}{$\begin{array}{c}\text { Оценка обеспеченности кадровым резервом должностей, } \\
\text { подлежащих обеспечению резервом (ПОР) }\end{array}$} \\
\hline 1 & $\begin{array}{l}\text { Общая обеспеченность } \\
\text { резервом }\end{array}$ & $\begin{array}{l}\mathrm{K}_{\text {ОБщ }}=\frac{\mathrm{Ч}_{\text {здпор }}}{\mathrm{\Psi}_{\text {овщ }}} \times 100 \%=\frac{18}{18} \times 100 \%=100, \\
\text { где } \mathrm{Ч}_{\text {здпоР }}-\text { количество должностей ПОР, для которых соз- } \\
\text { дан кадровый резерв; } \\
\mathrm{Ч}_{\text {овщ }}-\text { общее количество должностей ПОР в подразделении. }\end{array}$ \\
\hline 2 & $\begin{array}{l}\text { Средний возраст } \\
\text { резервистов, состоящих } \\
\text { в кадровом резерве } \\
\text { на должности ПОР }\end{array}$ & $\begin{array}{l}\overline{\mathrm{B}}_{\mathrm{PE} 3}=\frac{\sum \mathrm{B}_{\mathrm{PE} 3}}{\mathrm{Ч}_{\mathrm{PE3}}}=\frac{755}{18}=41,9, \\
\text { где } \sum \mathrm{B}_{\mathrm{PE3}}-\text { сумма возрастов резервистов подразделения; } \\
\mathrm{Ч}_{\mathrm{PE3}}-\text { общее количество резервистов в подразделении. }\end{array}$ \\
\hline 3 & $\begin{array}{l}\text { Средний возраст } \\
\text { руководителей, } \\
\text { занимающих } \\
\text { должности ПОР }\end{array}$ & $\begin{array}{l}\overline{\mathrm{B}}_{\text {Рук }}=\frac{\sum \mathrm{B}_{\text {рук }}}{\mathrm{Ч}_{\text {рук }}}=\frac{902}{18}=50,1, \\
\text { где } \sum \mathrm{B}_{\text {рук }}-\text { сумма возрастов работников, занимающих долж- } \\
\text { нос й ПОР в подразделении; } \\
\mathrm{Ч}_{\text {рук }}-\text { общее количество работников, занимающих должно- } \\
\text { сти ПОР в подразделении. }\end{array}$ \\
\hline \multicolumn{3}{|c|}{ Оценка изменения состава кадрового резерва } \\
\hline 4 & $\begin{array}{l}\text { Текучесть среди } \\
\text { резервистов }\end{array}$ & $\begin{array}{l}\mathrm{K}_{\mathrm{TEK}}=\frac{\mathrm{Ч}_{\mathrm{yP}}}{\mathrm{Ч}_{\mathrm{PE3}}} \times 100 \%=\frac{2}{18} \times 100 \%=11,1, \\
\text { где } \mathrm{Ч}_{\text {ур }}-\text { количество уволенных из подразделения резерви- } \\
\text { стов по причинам текучести. }\end{array}$ \\
\hline 5 & $\begin{array}{l}\text { Целевое назначение } \\
\text { резервистов } \\
\text { на должность }\end{array}$ & $\begin{array}{l}\mathrm{K}_{\text {LНР }}=\frac{\mathrm{Ч}_{\text {ЦHР }}}{\mathrm{Ч}_{\mathrm{OH}}} \times 100 \%=\frac{3}{4} \times 100 \%=75,0, \\
\text { где Ч ЧНР }- \text { количество резервистов в подразделении, назна- } \\
\text { ченных на должность из состава кадрового резерва на дан- } \\
\text { ную должность; } \\
\mathrm{Ч}_{\text {ОН }}-\text { общее количество всех работников, назначенных на } \\
\text { должности ПОР в подразделении }\end{array}$ \\
\hline 6 & $\begin{array}{l}\text { Назначение } \\
\text { не из резерва }\end{array}$ & $\begin{array}{l}\kappa_{\text {HнР }}=\frac{\mathrm{Ч}_{\mathrm{HнP}}}{\mathrm{Ч}_{\mathrm{OH}}} \times 100 \%=\frac{2}{4} \times 100 \%=50, \\
\text { где } Ч_{\text {ннР }}-\text { количество назначенных работников на должность } \\
\text { ПОР не из состава кадрового резерва на данную должность } \\
\text { при условии, что в согласованных списках резерва на дан- } \\
\text { ную должность указан резервист. }\end{array}$ \\
\hline
\end{tabular}


Окончание табл. 3.

\begin{tabular}{|c|c|c|}
\hline 7 & $\begin{array}{l}\text { Общее выбытие } \\
\text { из резерва }\end{array}$ & $\begin{array}{l}\text { К }_{\text {ОБщ.выБ. }}=\frac{\mathrm{Ч}_{\text {ОБщ.выБ. }}}{\mathrm{Ч}_{\text {рЕз3 }}} \times 100 \%=\frac{3}{19} \times 100 \%=15,8, \\
\text { где Ч ОБщ. выБ. }- \text { общее количество резервистов, выбывших из } \\
\text { состава резерва в подразделении по всем причинам. }\end{array}$ \\
\hline 8 & $\begin{array}{l}\text { Выбытие из резерва } \\
\text { по неуважительным } \\
\text { причинам }\end{array}$ & $\begin{array}{l}\text { К }_{\text {выБ. }}=\frac{\mathrm{Ч}_{\text {выБ. }}}{\mathrm{Ч}_{\text {РЕз. }}} \times 100 \%=\frac{0}{19} \times 100 \%=0, \\
\text { где } \mathrm{Ч}_{\text {выБ. }}-\text { количество резервистов, выбывших из состава } \\
\text { резерва по неуважительным причинам. }\end{array}$ \\
\hline \multicolumn{3}{|r|}{ Оценка подготовленности резерва } \\
\hline 9 & $\begin{array}{l}\text { Общая полная } \\
\text { подготовленность } \\
\text { резерва }\end{array}$ & $\begin{array}{l}\mathrm{K}_{\text {ПР }}=\frac{\mathrm{Ч}_{П Р}}{\mathrm{Ч}_{\text {ОБщ }}} \times 100 \%=\frac{5}{18} \times 100 \%=27,8, \\
\text { где } \mathrm{Ч}_{\text {ПР }}-\text { количество должностей ПОР, в резерве на которые } \\
\text { стоят полностью подготовленные резервисты. }\end{array}$ \\
\hline 10 & $\begin{array}{l}\text { Текущий уровень под- } \\
\text { готовленности резерви- } \\
\text { стов в подразделении }\end{array}$ & $\begin{array}{l}\text { Кугр }_{\text {у }}=\frac{Ч_{\text {Угр }}}{\mathrm{Ч}_{\text {ОБщ }}} \times 100 \%=\frac{6}{18} \times 100 \%=33,3, \\
\text { где Ч Чгр }- \text { количество резервистов в подразделении, имею- } \\
\text { щих определенный уровень подготовленности. }\end{array}$ \\
\hline
\end{tabular}

Анализируя данные таблицы 4, целесообразно обратить внимание на средний возраст резервистов - 41,9 лет. Показатель текучести среди резервистов согласно Положению о работе с кадровым резервом отклонен от нормы на 6,1\%. Это обусловлено увольнением по собственному желанию 2 резервистов в 2019 г. Особо интересен показатель «Назначение на руководящие должности не из резерва», составляющий 50\% от общего числа ключевых должностей предприятия. Значит, что предприятие не всегда ориентировано на закрытие вакантных ключевых должностей силами кадрового резерва.

Заключительным этапом исследования кадрового резерва явилось практическое применение социально-психологического метода посредством анкетирования начальника отдела управления персоналом промышленного предприятия, результаты которого представлены в таблице 4.

Таблицуа 4.

Результаты анкетирования начальника отдела по управлению персоналом промышленного предприятия Красноярского края

\begin{tabular}{|c|l|c|c|}
\hline$№$ & \multicolumn{1}{|c|}{ Вопрос } & Ответ & Баллы \\
\hline 1 & $\begin{array}{l}\text { Как Вы подбираете руководителей подразделений предпри- } \\
\text { ятия? }\end{array}$ & $\begin{array}{c}\text { Кадровый } \\
\text { резерв }\end{array}$ & 2 \\
\hline 2 & $\begin{array}{l}\text { Выгодно ли Вам включать 2-3 сотрудников в кадровый резерв на } \\
\text { одну должность на случай, если кто-то из них вдруг уволится? }\end{array}$ & Да & 2 \\
\hline
\end{tabular}


Окончание табл. 4.

\begin{tabular}{|c|c|c|c|}
\hline 3 & $\begin{array}{l}\text { Выгодно ли готовить кадровый резерв для вновь созданных } \\
\text { должностей? }\end{array}$ & Нет & 1 \\
\hline 4 & $\begin{array}{l}\text { Будете ли Вы ждать пока сотрудник «вырастет» или обрати- } \\
\text { тесь на рынок труда и «купите готового» руководителя? }\end{array}$ & \begin{tabular}{|c|} 
Будем \\
ждать, мы \\
нуждаем- \\
ся в про- \\
фессиона- \\
лах \\
\end{tabular} & 2 \\
\hline 5 & $\begin{array}{l}\text { Вы уверены, что не потеряете сотрудников, не включенных в } \\
\text { кадровый резерв? }\end{array}$ & \begin{tabular}{|c|} 
Не увере- \\
ны, нужна \\
дополни- \\
тельная \\
мотивация \\
\end{tabular} & 1 \\
\hline 6 & $\begin{array}{l}\text { Как часто ключевую должность занимает сотрудник не из ка- } \\
\text { дрового резерва, при условии, что имеются подготовленные } \\
\text { сотрудники для данной должности? }\end{array}$ & Редко & 1 \\
\hline 7 & $\begin{array}{l}\text { Вы уверены, что отобранные сотрудники не утратят свои зна- } \\
\text { ния, умения и навыки после включения их в кадровый резерв? }\end{array}$ & \begin{tabular}{|c|} 
Необхо- \\
дима \\
аттестация \\
персонала
\end{tabular} & 1 \\
\hline 8 & $\begin{array}{l}\text { Проводите ли Вы опрос среди сотрудников, не включенных в } \\
\text { кадровый резерв? }\end{array}$ & Нет & 0 \\
\hline 9 & $\begin{array}{l}\text { Как думаете, сохранится ли лояльность к предприятию у со- } \\
\text { трудников, не включенных в кадровый резерв? }\end{array}$ & $\begin{array}{l}\text { Скорее } \\
\text { нет, } \\
\text { чем да }\end{array}$ & 1 \\
\hline 10 & Каким образом осуществляется отбор в кадровый резерв? & \begin{tabular}{|c|} 
По ре- \\
зультатам \\
деятель- \\
ности
\end{tabular} & 1 \\
\hline 11 & $\begin{array}{l}\text { Вы уверены, что все резервисты, которых вы подготовили, бу- } \\
\text { дут востребованы на ключевые должности в течение } 3-5 \text { лет? }\end{array}$ & Нет & 1 \\
\hline 12 & $\begin{array}{l}\text { Имеются ли индивидуальные планы развития сотрудников на } \\
\text { предприятии? }\end{array}$ & Да & 2 \\
\hline 13 & Как проходит развитие сотрудников-резервистов? & \begin{tabular}{c|} 
Изучение \\
докумен- \\
тов
\end{tabular} & 1 \\
\hline 14 & $\begin{array}{l}\text { Согласно какого документа Вы осуществляете отбор персона- } \\
\text { ла в кадровый резерв? }\end{array}$ & \begin{tabular}{|c|} 
Поло- \\
жение о \\
работе с \\
кадровым \\
резервом
\end{tabular} & 2 \\
\hline
\end{tabular}

Общее количество баллов составило 18. Согласно интерпретации, данный результат характеризует работу кадрового резерва в выбранном объекте исследования на среднем уровне. 
Таким образом, исследование работы с кадром резервом на промышленном предприятии Красноярского края позволяет сформулировать следующие проблемы:

1) высокий коэффициент текучести среди резервистов;

2) отсутствие практической подготовки резервистов;

3) процедура выдвижения кандидатов на ключевую должность не регламентирована.

\section{Результаты и обсуждение}

В этой связи для совершенствования работы кадрового резерва как направления развития персонала на промышленном предприятии Красноярского края предлагаем рекомендации, представленные в таблице 5.

Таблица 5 .

Рекомендации по совершенствованию кадрового резерва как направления развития персонала на промышленном предприятии Красноярского края

\begin{tabular}{|c|c|c|}
\hline Проблема & Рекомендация & Мероприятия \\
\hline $\begin{array}{l}\text { 1) Высокий } \\
\text { коэффициент } \\
\text { текучести среди } \\
\text { резервистов }\end{array}$ & $\begin{array}{l}\text { Управление } \\
\text { текучестью } \\
\text { кадров среди } \\
\text { резервистов }\end{array}$ & $\begin{array}{l}\text { 1. Разработка анкеты для увольняющегося } \\
\text { резервиста. } \\
\text { 2. Организация семинара «Будущее резервиста». } \\
\text { 3. Организация семинара «Открытая полити- } \\
\text { ка» между резервистами и высшим руковод- } \\
\text { ством предприятия. }\end{array}$ \\
\hline $\begin{array}{l}\text { 2) Отсутствие } \\
\text { практической } \\
\text { подготовки ре- } \\
\text { зервистов }\end{array}$ & $\begin{array}{l}\text { Совершен- } \\
\text { ствование } \\
\text { плана инди- } \\
\text { видуального } \\
\text { развития ре-- } \\
\text { зервистов } \\
\end{array}$ & $\begin{array}{l}\text { 1. Изменение Положения о работе с кадро- } \\
\text { вым резервом. } \\
\text { 2. Вовлечение резервистов в проекты, рас- } \\
\text { ширяющие профессиональные интересы. } \\
\text { 3. Организация стажировок на другие про- } \\
\text { мышленные предприятия. }\end{array}$ \\
\hline \begin{tabular}{l|} 
3) Процедура \\
выдвижение \\
кандидатов на \\
ключевую долж- \\
ность не регла- \\
ментирована
\end{tabular} & \begin{tabular}{|l|} 
Регламента- \\
ция проце- \\
дуры вы- \\
движения \\
кандидатов \\
на ключевую \\
должность \\
\end{tabular} & $\begin{array}{l}\text { 1. Изменение Положения по подбору персонала. } \\
\text { 2. Изменение Положения о Кадровой политике. } \\
\text { 3. Изменение Положение о работе с кадро- } \\
\text { вым резервом. }\end{array}$ \\
\hline
\end{tabular}

Рассмотрим детальнее предложенные рекомендации.

Результаты исследования указали на превышение нормы текучести среди сотрудников - резервистов, прописанной в Положении о 
работе с кадровым резервом на предприятии. В этой связи рекомендуем управление текучестью кадров среди резервистов посредством разработки анкеты для увольняющегося резервиста и организации семинаров «Будущее резервиста» и «Открытая политика» между резервистами и высшим руководством предприятия.

На данный момент на предприятии отсутствует анкета для увольняющихся сотрудников, внедрение которой позволит определять объективные причины увольнения персонала и проблемы в управлении кадровым резервом. Предлагаемая анкета представлена таблице 6.

Таблица 6.

Анкета увольняющегося сотрудника-резервиста

\begin{tabular}{|c|c|c|}
\hline № & Вопрос & Варианты ответов \\
\hline 1 & $\begin{array}{l}\text { Что препятствовало } \\
\text { Вашей трудовой } \\
\text { деятельности } \\
\text { на предприятии? }\end{array}$ & $\begin{array}{l}\text { a) отсутствие карьерного роста } \\
\text { б) недостаточный уровень обучения по профессии } \\
\text { в) отсутствие четких указаний, инструкций от- } \\
\text { носительно выполняемой работы } \\
\text { г) моей деятельности ничто не мешало } \\
\text { Другое } \\
\end{array}$ \\
\hline 2 & $\begin{array}{l}\text { Как Вы оцениваете } \\
\text { наше предприятие } \\
\text { в целом? }\end{array}$ & $\begin{array}{l}\text { а) неблагоприятная экологическая обстановка на } \\
\text { предприятии } \\
\text { б) тяжелые условия труда (шум, грязь, пыль, холод) } \\
\text { в) нехватка необходимых материалов, инстру- } \\
\text { ментов для полноценной работы } \\
\text { г) отношения в коллективе дружеские, любой мо- } \\
\text { жет рассчитывать на помощь и взаимопонимание } \\
\text { д) отношения в коллективе напряженные, каж- } \\
\text { дый сам за себя } \\
\text { Другое }\end{array}$ \\
\hline 3 & $\begin{array}{l}\text { Удовлетворяла ли Вас } \\
\text { оплата труда по зани- } \\
\text { маемой должности? }\end{array}$ & $\begin{array}{l}\text { a) да } \\
\text { б) нет } \\
\text { Другое }\end{array}$ \\
\hline 4 & $\begin{array}{l}\text { Как Вы относились к } \\
\text { тому, что руководящие } \\
\text { должности предпри- } \\
\text { ятия иногда занима- } \\
\text { лись сотрудниками со } \\
\text { стороны, в то время } \\
\text { как на предприятии } \\
\text { имелись подготовлен- } \\
\text { ные руководители? } \\
\end{array}$ & $\begin{array}{l}\text { a) полностью согласен с решением высшего ру- } \\
\text { ководства } \\
\text { б) полностью не согласен с решением высшего } \\
\text { руководства } \\
\text { в) для меня это не имеет значения }\end{array}$ \\
\hline
\end{tabular}


Окончание табл. 6.

\begin{tabular}{|c|c|c|}
\hline 5 & $\begin{array}{l}\text { Как часто в Вашем } \\
\text { отделе проводились } \\
\text { собрания на тему слу- } \\
\text { жебно-профессиональ- } \\
\text { ного продвижения? }\end{array}$ & $\begin{array}{l}\text { a) } 1 \text { раз в квартал } \\
\text { б) } 1 \text { раз в полугодии } \\
\text { в) никогда не проводились подобного рода ме- } \\
\text { роприятия }\end{array}$ \\
\hline 6 & $\begin{array}{l}\text { Удалось ли Вам постро- } \\
\text { ить свою карьеру на на- } \\
\text { шем предприятии? }\end{array}$ & $\begin{array}{l}\text { a) да } \\
\text { б) нет } \\
\text { в) не планировал карьеру на Вашем предприятии }\end{array}$ \\
\hline 7 & $\begin{array}{l}\text { Укажите основные } \\
\text { причины, по которым } \\
\text { Вам не удалось по- } \\
\text { строить карьеру на на- } \\
\text { шем предприятии? }\end{array}$ & $\begin{array}{l}\text { a) не было возможности в полной мере актуали- } \\
\text { зировать свой потенциал } \\
\text { б) редкое освобождение вакантных должностей } \\
\text { в) не был зачислен в кадровый резерв предприятия } \\
\text { г) на предприятии отсутствуют возможности для } \\
\text { развития персонала } \\
\text { Другое }\end{array}$ \\
\hline 8 & $\begin{array}{l}\text { Если Вы уже подыска- } \\
\text { ли себе новое место ра- } \\
\text { боты, что именно Вас } \\
\text { там заинтересовало? }\end{array}$ & $\begin{array}{l}\text { a) уровень оплаты труда намного выше для моей } \\
\text { квалификации, чем на Вашем предприятии } \\
\text { б) мне предложили руководящую должность на } \\
\text { новом месте } \\
\text { в) эта работа находится ближе к моему месту } \\
\text { жительства } \\
\text { Другое }\end{array}$ \\
\hline 9 & $\begin{array}{l}\text { Что может удержать } \\
\text { Вас на данном пред- } \\
\text { приятии? }\end{array}$ & $\begin{array}{l}\text { a) повышение } 3 / \text { п } \\
\text { б) повышение в должности } \\
\text { в) ничего } \\
\end{array}$ \\
\hline 10 & $\begin{array}{l}\text { Будете ли Вы рекомен- } \\
\text { довать своим знакомым } \\
\text { наше предприятие в } \\
\text { качестве возможного } \\
\text { места работы? }\end{array}$ & $\begin{array}{l}\text { а) да } \\
\text { б) нет } \\
\text { Другое }\end{array}$ \\
\hline 11 & $\begin{array}{l}\text { Вы уже подыскали } \\
\text { себе новое место } \\
\text { работы? }\end{array}$ & $\begin{array}{l}\text { a) да } \\
\text { б) нет } \\
\text { Другое }\end{array}$ \\
\hline
\end{tabular}

Для чёткого понимания резервистом своего будущего на данном предприятии предлагаем на его базе организовать семинар «Будущее резервиста», программа которого включает следующие вопросы:

- как организована работа с кадровым резервом?

- какое количество резервируемых должностей на предприятии и их наименование?

- каков порядок пополнения кадрового резерва?

- как организованы изменения количественного и качественного состава персонала. 
Дополнительно отметим отсутствие практики обратной связи между сотрудниками - резервистами и руководством предприятия. Однако, по мнению психологов, обратная связь является одним из действенных инструментов развития персонала. В этой связи значимость и актуальность приобретает семинар «Открытая политика» продолжительностью два рабочих дня. В первый день планируется раскрыть вопросы развития резервистов. Второй день - организовать с помощью метода мозгового штурма. Каждому резервисту будет предоставлена возможность оценить работу с кадровым резервом, сформулировать рекомендации по ее совершенствованию.

Следующей рекомендацией является совершенствование плана индивидуального развития резервистов. Как показали результаты проведённого исследования, на предприятии отсутствует практический опыт резервиста, совмещение смежных профессий и т.д., наблюдается только ознакомление с документацией по той или иной должности. В качестве примера, представим фрагмент плана индивидуального развития начальника цеха предприятия, который наглядно отражен в таблице 7.

Таблица 7.

Фрагмент индивидуального плана развития участника кадрового резерва промышленного предприятия Красноярского края

\begin{tabular}{|c|c|c|c|}
\hline \multicolumn{4}{|c|}{ I Корпоративные компетенции } \\
\hline № & Компетенции & $\begin{array}{c}\text { Что конкретно планиру- } \\
\text { ется развивать }\end{array}$ & $\begin{array}{c}\text { Мероприятия, направленные на } \\
\text { развитие компетенции }\end{array}$ \\
\hline 1 & $\begin{array}{l}\text { Управление } \\
\text { людьми }\end{array}$ & $\begin{array}{l}\text { Делегирование полно- } \\
\text { мочий. } \\
\text { Конструктивная кри- } \\
\text { тика. }\end{array}$ & $\begin{array}{l}\text { - анализ системы постановки } \\
\text { задач руководителями групп, } \\
\text { участков; } \\
\text { - анализ распределения обя- } \\
\text { занностей, полномочий; } \\
\text { - разработка плана мероприя- } \\
\text { тий по результатам анализа; } \\
\text { - закрепление наставника для } \\
\text { назначенного заместителя на- } \\
\text { чальника цеха. }\end{array}$ \\
\hline 2 & $\begin{array}{l}\text { Коммуника- } \\
\text { ции }\end{array}$ & $\begin{array}{l}\text { Умение слушать и слы- } \\
\text { шать. Способность идти } \\
\text { на компромисс. }\end{array}$ & $\begin{array}{l}\text { - вебинары, консультации на- } \\
\text { ставника. }\end{array}$ \\
\hline
\end{tabular}


Окончание табл. 7.

\begin{tabular}{|c|c|c|}
\hline \multicolumn{3}{|r|}{ II Профессиональные компетенции } \\
\hline № & $\begin{array}{l}\text { Знания/ умения / } \\
\text { навыки }\end{array}$ & Мероприятия \\
\hline 1 & $\begin{array}{l}\text { - знание основ } \\
\text { экономики } \\
\text { предприятия; } \\
\text { - знание рынка } \\
\text { электроэнер- } \\
\text { гии/ мощно- } \\
\text { сти }\end{array}$ & $\begin{array}{l}\text { - саморазвитие (чтение специализированной профес- } \\
\text { сиональной литературы); } \\
\text { - организация замещения ключевой должности пред- } \\
\text { приятия внутри организации в период отсутствия } \\
\text { руководителя подразделения, цеха, отдела (команди- } \\
\text { ровка, отпуск, больничный лист; } \\
\text { - организация стажировок на смежных по профилю } \\
\text { деятельности предприятиях. }\end{array}$ \\
\hline 2 & $\begin{array}{l}\text { - знание техно- } \\
\text { логических } \\
\text { процессов } \\
\text { электроэнерге- } \\
\text { тике; } \\
\text { - обеспечение } \\
\text { повышения } \\
\text { безопасности } \\
\text { труда персо- } \\
\text { нала предпри- } \\
\text { ятия }\end{array}$ & $\begin{array}{l}\text { - саморазвитие (чтение специализированной профес- } \\
\text { сиональной литературы); } \\
\text { - создание системы оповещения и управления эвакуа- } \\
\text { цией персонала при пожаре; } \\
\text { - создание системы принятия решений на базе данных } \\
\text { информационных устройств предприятия. }\end{array}$ \\
\hline \multicolumn{3}{|r|}{ III Проект ПС } \\
\hline № & & Название проекта \\
\hline 1 & $\begin{array}{l}\text { «Снижение затрат } \\
\text { мы электронного } \\
\text { ЕСЭ-Инжинирин } \\
\text { внедрения и доку }\end{array}$ & $\begin{array}{l}\text { г на тиражирование и техническую поддержку систе- } \\
\text { документооборота WSS Docs в компаниях ECЭ (ИЭСК, } \\
\text { г, КраМЗ-Телеком) за счет стандартизации процессов } \\
\text { ментационного обеспечения». }\end{array}$ \\
\hline
\end{tabular}

Изменение Положения о работе с кадровым резервом промышленного предприятия заключается в расширении спектра обучающих и развивающих мероприятий. В частности, предлагаем замещение ключевой должности в период короткого/ длительного отсутствия руководителя подразделения, цеха, отдела. Это играет значимую роль в профессиональной деятельности резервиста, поскольку позволяет развивать SoftSkills \& HardSkills, необходимые для резервируемой должности.

Для расширения сферы деятельности резервистов предлагается вовлекать их в действующие проекты предприятия. Это способствует формированию заинтересованности резервиста в успехе проекта 
и предприятия в целом. Вовлеченность в проект оказывает не только поддержку и мотивирует резервиста, но и способствует нахождению новых и более продуктивных способов реализации профессиональной деятельности.

В частности, предлагаем вовлечь в проект «Снижение затрат на тиражирование и техподдержку системы электронного документооборота WSS Docs в компаниях ECЭ за счёт стандартизации процессов внедрения и документационного обеспечения». Стратегические цели проекта:

- снижение затрат на тиражирование СЭД с 2710 тыс. руб. до 80 тыс. руб. за счёт организации процессов тиражирования собственными силами;

- снижение стоимости техподдержки одного пользователя в месяц с 0,5 тыс. руб. до 0,08 тыс. руб. за счёт сохранения состава группы техподдержки.

Задачи по проекту определены в виде направлений работ по достижению стратегических целей:

- исключение потерь в работе оборудования и его оптимальное использование;

- выявление и исключение простоев, излишних действий в работе персонала, выполняющих настройку и техподдержку системы.

Дополнительно для приобретения опыта профессиональной деятельности предлагаем организовать стажировки на смежных по профилю деятельности предприятиях, предприятиях - партнерах. Это обеспечит сбалансированное сочетание теоретического материала и практических примеров. В частности, резервисты изучат опыт своих коллег, например, по использованию уникального оборудования, работе в схожих климатических условиях. Обмен опытом между предприятиями позволит определить собственные успехи и неудачи, получить знания о передовых технологиях отрасли и т. д.

Следующей рекомендацией является регламентация процедуры выдвижения кандидатов на ключевую должность. Для этого необходимо внести изменения в Положение по подбору персонала, Положение о Кадровой политике и в Положение о работе с кадровым резервом. 
Согласно Положению по подбору персонала, потребность в ключевой должности покрывается за счёт внешних и внутренних ресурсов предприятия. В ходе исследования определено, что в 2019 2020 гг. дважды ключевые должности покрывались из внешних ресурсов. Причем на предприятии имелись подготовленные резервисты для закрытия вакантных должностей. Следовательно, считаем целесообразным дополнить Положение по подбору персонала следующим содержанием - подбор кандидата на ключевую должность осуществляется из внешних источников в единственном случае, при отсутствии подготовленного резервиста для замещения ключевой позиции. Если такой сотрудник имеется, то вакансия закрывается внутренними ресурсами предприятия (силами кадрового резерва).

Кадровая политика предприятия тесно связана с его производственной и управленческой деятельностью, которые реализуются руководство. При этом в основных направлениях и задачах Кадровой политики предприятия отсутствует такое направление как совершенствование и развитие кадрового резерва. Соответственно, считаем необходимым его включить.

Дополнительно предлагается внести изменения в Положение о работе с кадровым резервом. Формирование кадрового резерва является одной из форм развития персонала организации и частью работы по планированию карьеры. В этой связи предлагаем в данный документ включить основные принципы построения карьеры, в качестве которых определены непрерывность, осмысление, скорость, манёвренность, экономичность. Внесенные изменения, по нашему мнению, позволят создать понятные маршруты карьерного роста.

Таким образом, на основании выявленных проблем в работе с кадровым резервом на промышленном предприятии Красноярского края представлены рекомендации по их устранению. Для каждой рекомендации предложены мероприятия, которые, на наш взгляд, способны улучшить работу с кадровым резервом. Правильная организация работы с кадровым резервом является, с одной стороны, индикатором компетентности управленческой вертикали, а с другой - залогом эффективности функционирования предприятия в целом. 


\section{Заключение}

В статье представлены теоретические основы работы с кадровым резервом как направления развития персонала промышленного предприятия. В результате чего определен понятийный аппарат, обоснованы методы и представлены материалы исследования, сформулированы основные рекомендации по совершенствованию работы с кадровым резервом как направления развития персонала на промышленном предприятии Красноярского края.

В целом, согласно цели и задачам исследования, можно сделать следующие основные выводы.

Во-первых, уточнено содержание понятий «развитие персонала» и «кадровый резерв».

Во-вторых, проведено исследование работы с кадром резервом на промышленном предприятии Красноярского края. В результате определены проблемы - высокий коэффициент текучести среди резервистов, отсутствие практической подготовки резервистов, процедура выдвижения кандидатов на ключевую должность не регламентирована.

B-третьих, разработаны и предложены рекомендации и мероприятия по совершенствованию работы с кадровым резервом как направления развития персонала на промышленном предприятии Красноярского края. В частности, в качестве рекомендаций определены управление процессом текучести среди резервистов, совершенствование плана индивидуального развития резервистов, регламентация процедуры выдвижения кандидатов на ключевую должность.

Таким образом, цель достигнута, задачи исследования выполнены, получены новые знания об исследуемом процессе, выводы не претендуют на исчерпывающее решение исследуемой проблемы, предлагается лишь один из путей ее решения.

\section{Список литературы}

1. Аристархова А.К., Шендель Т.В. Совершенствование кадрового резерва как направление развития персонала промышленного предприятия // Актуальные проблемы авиации и космонавтики: материалы XIV Международной научно-практической конференции, посвящен- 
ной Дню космонавтики / СибГУ им. М.Ф. Решетнева. Красноярск. 2018. Т. 3. № 4 (14). С. 340-343.

2. Богачева А.М., Соколова Е.Л. Система развития персонала и ее структурные элементы // Управление человеческими ресурсами основа развития инновационной экономики: материалы VI Международной научно-практической конференции. 2015. № 6. С. 334-339.

3. Данилова А.С., Леонович Е.И. Профессиональное развитие персонала: систематизация подходов // Современная экономика и общество глазами молодых исследователей: сборник статей участников Международной научно-практической конференции V Уральского вернисажа науки и бизнеса / Под общей редакцией Е.П. Велихова. Екатеринбург, 2018. С. 189-193.

4. Демидова Е.В. Гибкие навыки в системе личностных компетенций менеджера // Новое в психолого-педагогических исследованиях. 2019. № 3 (55). С. 100-108.

5. Демидова Е.В. Практическая психология в развитии SoftSkills // Управление человеческими ресурсами - основа развития инновационной экономики: материалы VIII Международной научно-практической конференции. 2019. № 8. С. 29-34.

6. Кутузова А.В. Управление кадровым резервом: пути совершенствования // Инновационные технологии на железнодорожном транспорте: труды XXII Межвузовской научно-практической конференции / Ответственный редактор В.С. Ратушняк. Красноярск. КрИЖТ ИрГУПС. 2018. С. 157-162.

7. Новикова С.С. Социологические и психологические методы исследований в социальной работе: Учебное пособие / Новикова С.С., Соловьев А.В. М.: НИЦ ИНФРА-М, 2016. 496 с.

8. Пугачёва Я.А., Яркова С.А. Методы оценки системы развития персонала в организации // Наукоемкие исследования как основа инновационного развития общества: сборник статей Международной научно-практической конференции. 2019. С. 209-213.

9. Таршис Е.Я. Контент-анализ: принципы методологии. Построение теоретической базы. Онтология, аналитика и феноменология текста. Программа исследования. М.: Книжный дом ЛИБРОКОМ, 2014. 182 с. 
10. Шендель Т. В. Проблемы планирования служебно-профессионального продвижения персонала предприятия // Инновационная экономика: перспективы развития и совершенствования. 2019. № 3 (37). C. 209-215.

11. Якимова Л.Д., Халикова А.Р. Создание стратегии развития кадрового потенциала // Современные проблемы развития экономики и управления в регионе: материалы X Международной научно-практической конференции. 2016. С. 456-459.

12. Application of talent management technology in work with personnel reserve of oil-and-gas company / Vinichenko M.V., Kirillov A.V., Melnichuk Y.A., Chulanova O.L., Korosteleva D.A. // Espacios. 2018. T. 39. № 48. C. 32.

13. Career opportunities for the management's personnel reserve / Kirillov A.V., Vinichenko M.V., Makuchkin S.A., MelnichukA.V., Ushakov D.S. // Eurasian Journal of Analytical Chemistry. 2017. T. 12. № 5b. C. 723-733.

14. Gnedenko M. Innovation tools for personnel assessment and development // International Journal of Applied and Fundamental Research. 2015. № 2. C. 82 .

15. Titova S.V., Medvedeva L.A. Integral index of company's personnel reserve operating efficiency // European Researcher. 2013. № 11-1 (62). C. 2598-2605.

\section{References}

1. Aristarhova A.K., Shendel' T.V. Aktual'nye problemy aviacii i kosmonavtiki Materialy XIV Mezhdunarodnoj nauchno-prakticheskoj konferencii, posvyashchennoj Dnyu kosmonavtiki [Actual problems of aviation and cosmonautics: materials of the XIV International scientific and practical conference dedicated to the day of cosmonautics]. Krasnoyarsk. 2018. Vol. 3. No. 4 (14), pp. 340-343.

2. Bogacheva A.M., Sokolova E.L. Upravlenie chelovecheskimi resursami - osnova razvitiya innovacionnoj ekonomiki: materialy VI Mezhdunarodnoj nauchno-prakticheskoj konferencii [Human resource management-the basis for the development of an innovative economy: proceedings of the VI International scientific and practical conference]. 2015. No. 6, pp. 334-339. 
3. Danilova A.S., Leonovich E.I. Sovremennaya ekonomika i obshchestvo glazami molodyh issledovatelej: sbornik statej uchastnikov Mezhdunarodnoj nauchno-prakticheskoj konferencii V Ural'skogo vernisazha nauki i biznesa [Modern economy and society through the eyes of young researchers: a collection of articles by participants of The international scientific and practical conference of the V Ural Vernissage of science and business]. Ekaterinburg. 2018, pp. 189-193.

4. Demidova E.V. Novoe v psihologo-pedagogicheskih issledovaniyah [New in psychological and pedagogical research]. 2019. No. 3 (55), pp. 100-108.

5. Demidova E.V. Upravlenie chelovecheskimi resursami-osnova razvitiya innovacionnoj ekonomiki: materialy VIII Mezhdunarodnoj nauchno-prakticheskoj konferencii [Upravlenie chelovecheskimi resursami - osnova razvitiya innovacionnoj ekonomiki: materialy VIII Mezhdunarodnoj nauchno-prakticheskoj konferencii]. 2019. No. 8. pp. 29-34.

6. Kutuzova A.V. Innovacionnye tekhnologii na zheleznodorozhnom transporte: trudy XXII Mezhvuzovskoj nauchno-prakticheskoj konferencii [Innovative technologies in railway transport: proceedings of the XXII Interuniversity scientific and practical conference]. Krasnoyarsk. 2018., pp. 157-162.

7. Novikova S.S. Sociologicheskie i psihologicheskie metody issledovanij $v$ social'noj rabote [Sociological and psychological research methods in social work]: textbook. M.: NIC INFRA-M, 2016. 496 p.

8. Pugachyova Ya.A., Yarkova S.A. Naukoemkie issledovaniya kak osnova innovacionnogo razvitiya obshchestva: sbornik statej Mezhdunarodnoj nauchno-prakticheskoj konferencii [Science-intensive research as the basis for innovative development of society: collection of articles of the International scientific and practical conference]. 2019, pp. 209-213.

9. Tarshis E.Ya. Kontent-analiz: principy metodologii. Postroenie teoreticheskoj bazy. Ontologiya, analitika i fenomenologiya teksta. Programma issledovaniya [Content analysis: principles of methodology. Building a theoretical base. Ontology, Analytics and phenomenology of the text. Research programme]. M.: Knizhnyj dom LIBROKOM, 2014. 182 p.

10. Shendel' T.V. Innovacionnaya ekonomika: perspektivy razvitiya i sovershenstvovaniya [Innovative economy: prospects for development and improvement]. 2019. No. 3 (37), pp. 209-215. 
11. Yakimova L.D., Halikova A.R. Sovremennye problemy razvitiya ekonomiki i upravleniya v regione: materialy X Mezhdunarodnoj nauchno-prakticheskoj konferencii [Modern problems of economic and management development in the region: materials of the $\mathrm{X}$ International scientific and practical conference]. 2016, pp. 456-459.

12. Vinichenko M.V., Kirillov A.V., Melnichuk Y.A., Chulanova O.L., Korosteleva D.A. Espacios. 2018. Vol. 39. No. 48. P. 32.

13. Kirillov A.V., Vinichenko M.V., Makuchkin S.A., Melnichuk A.V., Ushakov D.S. Eurasian Journal of Analytical Chemistry. 2017. Vol. 12. No. 5b, pp. 723-733.

14. Gnedenko M. International Journal of Applied and Fundamental Research. 2015. No. 2. P. 82.

15. Titova S.V., Medvedeva L.A. European Researcher. 2013. No. 11-1 (62), pp. 2598-2605.

\section{ДАННЫЕ ОБ АВТОРЕ}

Шендель Татьяна Владимировна, доцент, кандидат педагогических наук, доцент кафедры экономики труда и управления персоналом

Сибирский государственный университет науки и технологий имени академика М. Ф. Решетнева

проспект им. газеты Красноярский рабочий, 31, г. Красноярск, 660037, Российская Федерачия

Shendeltatjana@rambler.ru

\section{DATA ABOUT THE AUTHOR}

Shendel Tatyana Vladimirovna, Associate Professor, Candidate of Pedagogical Sciences, Associate Professor of the Department of labor Economics and Personnel Management

Reshetnev Siberian State University of Science and Technology 31, prospect named after the newspaper Krasnoyarsk worker, Krasnoyarsk, 660037, Russian Federation

Shendeltatjana@rambler.ru

SPIN-code: 8790-3327

ORCID: 0000-0003-0336-3707 